ANALISIS CAUSE EFFECT MENGENAI DAMPAK DARI IMPLEMENTASI BANDUNG SMART CITY

\author{
NILMA \\ Program Studi Informatika \\ Fakultas Teknik dan Ilmu Komputer \\ Universitas Indraprasta PGRI \\ Jl. Nangka No. 58 C, Tanjung Barat, Jagakarsa, Jakarta Selatan 12530 \\ Email: nilma23juli@gmail.com
}

\begin{abstract}
The concept of smart city is a way of connecting physical, social and economic infrastructure using ICT, which integrates all aspects to make cities more efficient and livable. Many obstacles or constraints when the concept of Smart cityhas been running in the city of Bandung, related to mapping the problems of the indicators or categories of urban structuring. This study aims to see the cause of effect on the city of Bandung which has implemented the concept of Smart city in each part of Bandung, using the method of cause effect or commonly called fishbone diagram. The result of the research shows that Man or HR factor, Method or Process, Machine or Technology, and Infrastructure play a role in mapping the problems of Bandung Smart city implementation. With the discovery of problems from aspects of human resources, Methods, Technology and Infrastructure make Bandung Smart city become one of the smart city model that implements communication and information technology in the country.
\end{abstract}

Keywords: Smart city, Smart city Bandung, Fishbone Diagram

Abstrak. Konsep smart city yaitu sebuah cara menghubungkan infrastruktur fisik, sosial dan ekonomi menggunakan ICT, yang mengintegrasikan semua aspek untuk membuat kota yang lebih efisien dan layak huni. Banyak hambatan atau kendala pada saat konsep Smart city sudah berjalan di kota Bandung, terkait pemetaan terhadap permasalahan dari indikator atau kategori penataan kota. Penelitian ini bertujuan untuk melihat sebab akibat mengenai kota Bandung yang sudah mengimplementasikan konsep Smart city di tiap bagian daerah Kota Bandung, dengan menggunakan metode cause effect atau yang biasa disebut fishbone diagram. Hasil penelitian menunjukan bahwa faktor Man atau SDM, Method atau Proses, Machine atau Teknologi, dan Infrastruktur berperan dalam pemetaan permasalahan dari implementasi Bandung Smart city. Dengan ditemukannya permasalahan dari aspek SDM, Metode, Teknologi dan Infrastruktur membuat Bandung Smart city menjadi salah satu model kota pintar yang mengimplementasikan komunikasi dan teknologi informasi di tanah air.

Kata Kunci: Smart city, Smart city Bandung, Fishbone Diagram

\title{
PENDAHULUAN
}

Cara menghubungkan infrastruktur fisik, sosial dan ekonomi dengan teknologi ICT, yang mengintegrasikan semua elemen dan membuat kota menjadi lebih efisien dan layak huni merupakan maksud dari konsep smart city. Menurut Frost \& Sullivan (2014) mengidentifikasi delapan aspek dari smart citydiantaranya smart governance, smart energy, smart building, smart mobility, smart infrastructure, smart technology, smart healthcare, dan smart citizen. Salah satu kota di Indonesia yang dapat menjadi smart citydi tanah air adalah kota Bandung.

Menilik dari implementasi mengenai konsep kota pintar di Bandung yang sedang berjalan, berkaitan dengan undang - undang mengenai Pemerintah Daerah melalui inovasi dalam UU No. 23 Tahun 2014 tentang Pemerintahan Daerah. Dalam Bab XXI bertajuk inovasi Daerah. Dari Pasal 386 hingga Pasal 390 UU 23/2014, menjelaskan bahwa dalam rangka peningkatan kinerja penyelenggaraan Pemerintahan Daerah, Pemerintah Daerah dapat melakukan inovasi. Inovasi yang dimaksud adalah semua bentuk pembaharuan dalam 
penyelenggaraan Pemerintahan Daerah. Dalam merumuskan kebijakan inovasi, prinsipnya Pemerintahan Daerah mengacu pada peningkatan efisiensi, perbaikan efektivitas, perbaikan kualitas pelayanan, tidak ada konflik kepentingan, berorientasi kepada kepentingan umum, dilakukan secara terbuka, memenuhi nilai-nilai kepatutan, dan dapat dipertanggung jawabkan hasilnya tidak untuk kepentingan diri sendiri.

\section{Tujuan Penelitian}

Dari aspek yang telah dikemukakan dalam permasalahan di kota Bandung diatas, maka tujuan penelitian adalah sebagai berikut:

1. Mengindentifikasi kategori Man atau SDM, Method atau Proses, Machine atau Teknologi, dan Infrastruktur, sebagai aspek permasalahan tata kelola dari Bandung Smart city.

2. Memetakan permasalahan utama dalam implementasi Smart citydi Bandung menggunakan metode cause effect atau fishbone diagram.

\section{Smart city}

Smart cityberarti kota pintar, merupakan suatu konsep pengembangan, penerapan, dan implementasi teknologi yang diterapkan disuatu daerah sebagai sebuah interaksi yang kompleks di antara berbagai sistem yang ada di dalamnya (Pratama, 2014). Tujuan untuk dari pendekatan smart cityuntuk mencapai informasi dan pengelolaan kota yang terintegrasi.

Keenam jenis pembagian smart citytersebut meliputi smart economy, smart mobility, smart governance, smart people, smart living, dan smart environment. (Dwita Widyaningsih, 2013).

\section{Smart Economy}

Implementasi dan penilaian smart citypada bagian (dimensi) smart economy meliputi dua hal, yakni proses inovasi (innovation) dan kemampuan daya saing (competitives). Kedua hal tersebut berguna untuk mencapai peningkatan ekonomi bangsa yang lebih baik dan pintar, sebab inovasi dan kemampuan daya saing merupakan modal utama untuk kemajuan bangsa serta peningkatan pembangunan sumber daya. Arah pembangunan sumber daya disuatu wilayah diwujudkan melalui peningkatan akses, pemerataan, relevansi, dan mutu layanan sosial dasar, peningkatan kualitas dan daya saing tenaga kerja, pengendalian jumlah dan laju pertumbuhan penduduk serta peningkatan partisipasi masyarakat dalam mewujudkan kesuksesan implementasi smart citydi kota Bandung.

2. Smart People

Pembangunan senantiasa membutuhkan modal, baik modal ekonomi (economic capital), modal manusia (human capital) maupun modal sosial (social capital) dalam mewujudkan kesuksesan implementasi smart citydi kota Bandung.

3. Smart Governance

Adanya kerja sama antara pemerintah dan masyarakat diharapkan dapat mewujudkan tata kelola dan jalannya pemerintahan yang bersih, jujur, adil, dan demokrasi, serta kualitas dan kuantitas layanan publik yang lebih baik dalam mewujudkan kesuksesan implementasi smart city di kota Bandung.

4. Smart Mobility

Pada smart mobility ini terdapat proses transportasi dan mobilitas yang smart, sehingga diharapkan tercipta layanan publik untuk transportasi dan mobilitas yang lebih baik serta menghapus permasalahan umum di dalam transportasi, misalkan macet, pelanggaran lalu lintas, polusi dan lain-lain dalam mewujudkan kesuksesan implementasi smart city di kota Bandung.

\section{Smart Environment}

Kriteria penilaian mencakup proses kelangsungan dan pengelolaan sumber daya yang lebih baik. Untuk mewujudkan smart environment perlu adanya beragam terapan aplikasi dan komputer dalam bentuk sensor network dan wireless sensor network, jaringan komputer, kecerdasan buatan, database sistem, mobile computing, sistem operasi, paralel computing, recognition(face recognition, image recognition), image processing, intellegence transport system, dan beragam teknologi lainnya yang terkait dengan pengelolaan lingkungan hidup dan manusia itu sendiri dalam mewujudkan kesuksesan implementasi smart city di kota Bandung.

6. Smart Living 
Smart living terdapat syarat dan kriteria serta tujuan untuk proses pengelolaan kualitas hidup dan budaya yang lebih baik dan pintar diantaranya :

1. Fasilitas-fasilitas pendidikan yang memadai

2. Penyediaan sarana, prasarana dan informasi terkait dengan potensi pariswisata daerah yang atraktif .

3. Infrastruktur teknologi informasi yang memadai dalam mewujudkan kesuksesan implementasi smart city di kota Bandung.

\section{Smart city Bandung}

Bandung adalah sebuah kota muda dan bersemangat yang berusahan untuk memperkuat reputasi pertumbuhannya sebagai kota teknologi di Indonesia Teknopolis. Bandung Smart citymerupakan skema dari kota pintar yang menggabungkan segala fungsi berkenaan dengan tata ruang kota. Segala problematika masyarakat ataupun tata ruang dan lainnya dapat secara real time diketahui dan dicari solusi terbaiknya dengan cepat. (Bandung Smart CityPeran Teknologi : 2016)

Bandung Command Center yang saat ini dimiliki oleh kota Bandung juga merupakan kolaborasi dari berbagai pihak. Bandung Command Center merupakan hasil kolaborasi antara pemerintah kota Bandung dengan IBM dan Lembaga Afiliasi Penelitian Industri (LAPI) ITB. Saat ini, Bandung Command Center berfungsi sebagai pusat terkumpulnya data-data terkait dengan kebutuhan Bandung Smart city. Mulai dari SKPD atau Satuan Kerja Perangkat Daerah, data dari masyarakat, sampai data dari internal ke luar, akan dipusatkan di sini. Aplikasi Panic Button Bandung juga terhubung langsung dengan Bandung Command Center.

\section{Fishbone Diagram}

Fishbone diagram (diagram tulang ikan-karena bentuknya seperti tulang ikan) sering juga disebut Cause-and-Effect Diagram atau Ishikawa Diagram diperkenalkan oleh Dr. Kaoru Ishikawa, seorang ahli pengendalian kualitas dari Jepang, sebagai satu dari tujuh alat kualitas dasar (7 basic quality tools). Fishbone diagram digunakan ketika kita ingin mengidentifikasi kemungkinan penyebab masalah dan terutama ketika sebuah team cenderung jatuh berpikir pada rutinitas (Tague, 2005, p. 247).

Suatu tindakan dan langkah improvement akan lebih mudah dilakukan jika masalah dan akar penyebab masalah sudah ditemukan. Manfaat fishbone diagram ini dapat menolong kita untuk menemukan akar penyebab masalah secara user friendly, tools yang user friendly disukai orang-orang di industri manufaktur di mana proses di sana terkenal memiliki banyak ragam variabel yang berpotensi menyebabkan munculnya permasalahan.

Fishbone diagram akan mengidentifikasi berbagai sebab potensial dari satu efek atau masalah, dan menganalisis masalah tersebut melalui sesi brainstorming. Masalah akan dipecah menjadi sejumlah kategori yang berkaitan, mencakup manusia, material, mesin, prosedur, kebijakan, dan sebagainya. Setiap kategori mempunyai sebab-sebab yang perlu diuraikan melalui sesi brainstorming. Kategori-kategori ini antara lain:

Kategori 6M yang biasa digunakan dalam industri manufaktur:

- Machine (mesin atau teknologi),

- Method (metode atau proses),

- Material (termasuk raw material, consumption, dan informasi),

- Man Power (tenaga kerja atau pekerjaan fisik) / Mind Power (pekerjaan pikiran: kaizen, saran, dan sebagainya),

- Measurement (pengukuran atau inspeksi), dan

- Milieu / Mother Nature (lingkungan).

Menemukan sebab-sebab potensial dengan cara brainstorming, Mengkaji dan menyepakati sebab-sebab yang paling mungkin, Kemudian selama sesi brainstorming hendaknya dirangkum ke dalam tabel. 


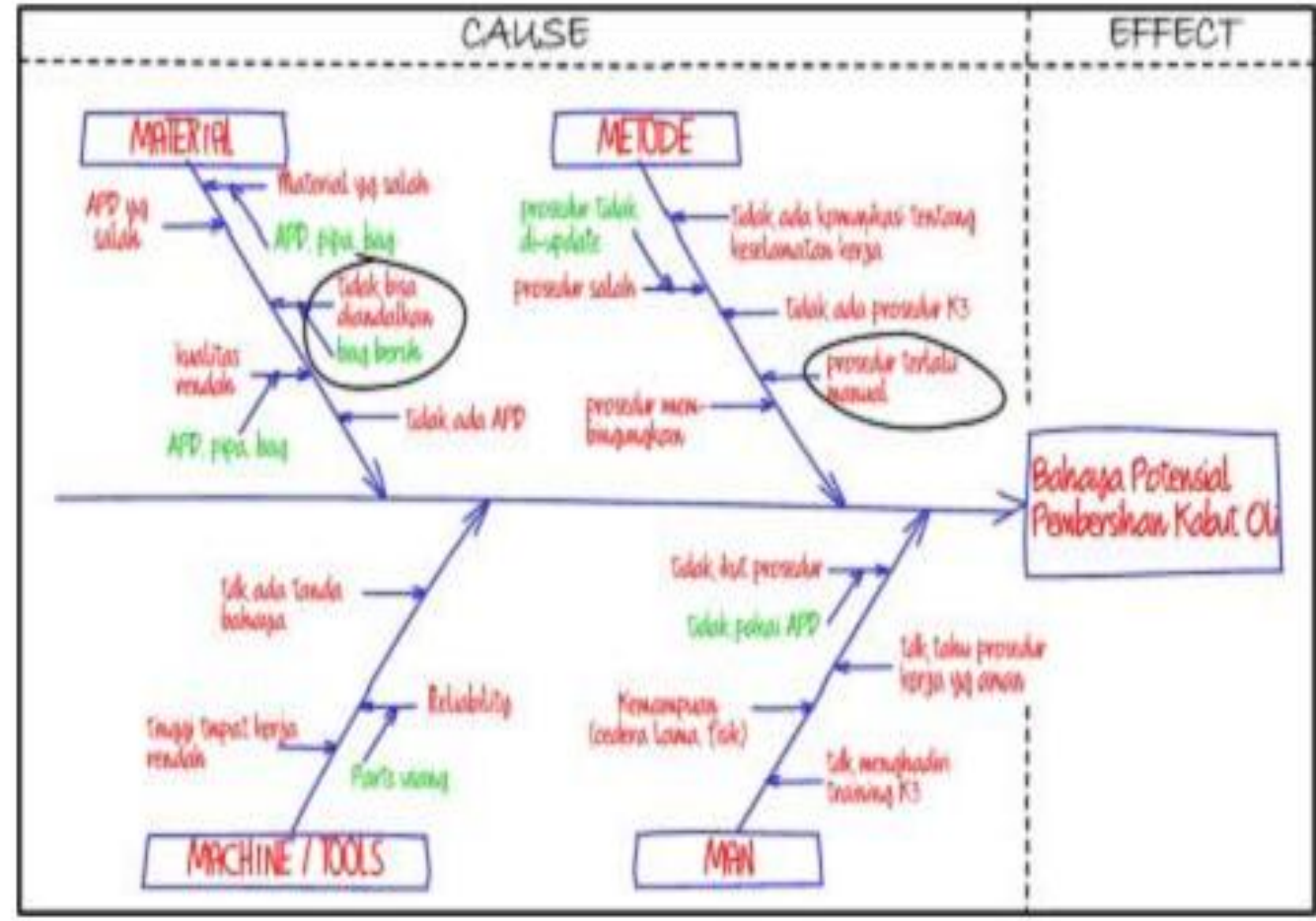

Gambar 1. Fishbone mengidentifikasi kategori

\section{Teori Relevan dari Peneliti Terdahulu}

1. Penelitian yang dilakukan oleh Dwita Widyaningsih (2013). "Kota Surabaya Menuju Smart city" Pada penelitian ini bertujuan Merumuskan tahapan-tahapan pembangunan, Menemukan struktur (pondasi dan pilar) proses pembangunan, Mengungkap aktor-aktor yang berperan dalam proses pembangunan, dan Mengungkap faktor-faktor yang mempengaruhi proses pembangunan Kota Surabaya menuju Smart City. Metode Penelitian berfokus pada proses pembangunan dan pencapaian-pencapaian program pembangunan hanya dibahas secara deskriptif dan kualitatif. Hasil penelitian Smart city di Kota Surabaya sudah mulai diterapkan dalam 6 komponen smart city yaitu smart government, smat living, smart environment, smart mobility, smart economy dan smart people. Terdapat 4 fase pembangunan menuju smart city yaitu fase pembenahan kinerja pemerintah, fase ke dua yakni mengembalikan kepercayaan masyarakat, fase ketiga yaitu pengembangan pelayanan berbasis tik, dan fase yang terakhir yaitu pengembangan sistem dengan teknologi tinggi.

2. Penelitian yang dilakukan oleh Siti Widharetno Mursalim (2017). "Implementasi Kebijakan Smart citydi Kota Bandung" Pada penelitian ini bertujuan Sosialisasi mengenai Smart cityyang belum merata, infrastruktur yang belum memadai, kurangnya pemahaman aparatur mengenai Smart city dan Sistem Operasional Prosedur hanya mengacu pada Roadmap Walikota Bandung. Metode penelitian dilakukan dengan analisis deskriptif dengan melakukan wawancara dan studi literatur. Hasil penelitian dapat mengetahui sosialisasi mengenai Smart city yang belum merata, infrastruktur yang belum memadai, kurangnya pemahaman aparatur mengenai Smart city dan Sistem Operasional Prosedur hanya mengacu pada Roadmap Walikota Bandung.

3. Penelitian yang dilakukan oleh Hafedh Chourabi, Tae woo Nam, Shawan Walker, J.Ramon GilGarcia, Sehl Mellouli, Karine Nahon, Theresa A. Pardo, dan Hans Jochen Scholl (2012). "Understanding Smart Cities:An Integrative Framework" Pada penelitian ini bertujuan Mengetahui kerangka atau ruang lingkup dalam memahami konsep smart cities. Metode penelitian dilakukan dengan studi literatur. Hasil penelitian 
konsep smart citydipahami melalui kerangka atau ruang lingkup yang dipengaruhi oleh dua faktor. Faktor tersebut adalah faktor luar dan dalam. Faktor dari luar meliputi pemerintah, individu,dan komunitas, lingkungan alam, infrastruktur,dan ekonomi. Adapun faktor luar meliputi teknologi, pengelolaan, dan kebijakan.

\section{METODE}

\section{Pengumpulan Data}

Metode pengumpulan data merupakan langkah yang paling strategis dalam penelitian, karena tujuan utama dari penelitian adalah mendapatkan data. Didalam kegiatan penelitian menjalankan dengan beberapa cara menurut Sugiyono (2013:224) yaitu:

1. Wawancara (Interview)

peneliti melakukan suatu metode suatu tanya jawab dengan pak Amiril mu"minin selaku humas smart city Bandung, mengenai semua tindakan yang berkaitan dengan Smart cityBandung.

2. Pengamatan (Observation)

Peneliti meninjau tindakan kegiatan yang berkaitan bersamaan problematika yang diangka. Hasil dari pengamatan tersebut langsung dicatat oleh peneliti dan dari kegiatan observasi dapat diketahui kesalahan atau proses dan kegiatan tersebut di Bandung Command Center bertempat di kantor Walikota Bandung, Jalan Wastukencana No.2 Bandung, Jawa Barat.

3. Studi Pustaka

Peneliti juga melakukan studi kepustakaan melalui literatur-literatur atau referensi-referensi yang ada di kantor Bandung digital valley maupun Bandung command center.

\section{Teknik Analisa Data}

Setelah melakukan metodologi penelitian diatas, langkah selanjutnya adalah peneliti menggunakan analisa sebab akibat atau cause effect atau yang lebih dikenal dengan analisa fishbone, guna memetakan masalah masalah utama yang berkaitan dengan implementasi dari dibangunnya konsep Bandung smart citysesuai dengan Undang - undang No. 23 Tahun 2014 BAB XXI Pasal 386-390 Tentang Inovasi Pemerintah Daerah.

\section{HASIL DAN PEMBAHASAN}

\section{Fishbone Diagram}

Dibawah ini merupakan analisa dampak implementasi smart citydikota Bandung menggunakan cause effect diagram atau fishbone diagram sebagai berikut :



Gambar 2. analisis fishbone diagram 
Terdapat empat kategori yang mengidentifikasi cakupan aspek Bandung Smart city yaitu disimpulkan dibawah ini :

\section{Man / SDM}

a) Tidak semua kalangan masyarakat dapat mengikuti dan menerapkan konsep yang dihadirkan oleh Bandung smart city, Hasil analisa adanya suatu ancaman dari masyarakat kecil atau bisa disebut kaum prasejahtera terkait ketidaknyamanan mereka selama adanya konsep smart city dibangun di kota Bandung, selain itu untuk generasi dibawah generasi milenal yang diharuskan mampu untuk menerapkan pola kota pintar pun juga perlu diperhatikan. Hal ini termasuk kedalam akar permasalahan yang harus segera ditangani.

b) Terkait dengan sistem pelayanan publik yang dilakukan pemerintahbelum semua memadai sesuai kebutuhan, Hasil analisa dibutuhkan tenaga ahli yang sesuai dengan kebutuhan guna menunjang kota pintar di Bandung, khususnya pelaksana organisasi pemerintah yang juga harus melek teknologi. Hal ini termasuk kedalam akar permasalahan yang harus segera ditangani.

c) Terkait perjanjian atau kontrak dengan vendor atau investor atau pelaku startup yang belum jelas perihal purna jual sistem, Hasil analisa mengenai berbagai aplikasi yang dihadirkan di Bandung smart city, tentu perlu tindak lanjut mengenai bagaimana kejelasan perihal vendor atau pelaku perusahaan rintisan untuk bekerja sama yang memang penting dalam mengembangkan kota pintar di Bandung. Hal ini termasuk kedalam akar permasalahan yang harus segera ditangani.

\section{Machine/Teknologi}

a) Beberapa aplikasi yang belum user friendly untuk masyarakat atau pemerintah setempat, Hasil analisa belum maksimal penggunaan sistem atau aplikasi yang tersedia karena pemahaman sebagian masyarakat masih minim. Hal ini termasuk kedalam akar permasalahan yang harus segera ditangani.

b) Belum pasti adanya pemeliharaan atau perawatan untuk aplikasi atau sistem yang terintegrasi oleh smart city di Bandung, Hasil analisa terkait mengenai purna jual sistem atau kerja sama antara pihak pemerintah dengan vendor atau pelaku rintisan yang bergabung masih ditindak lanjuti. Hal ini termasuk kedalam akar permasalahan yang harus segera ditangani.

c) Belum pasti keamanan sistem dari aplikasi - aplikasi khusus yang dihadirkan oleh smart city di Bandung, Hasil analisa membutuhkan teknologi khusus berkaitan dengan IoT atau internet of things disetiap aspek atau fungsi dari masing - masing sistem atau aplikasi yang terintegrasi. Hal ini termasuk kedalam akar permasalahan yang harus segera ditangani.

d) Pasokan tenaga listrik yang masih didistribusikan PLN, Hasil analisa membutuhkan smart Metode energi guna menghemat tenaga listrik untuk masyarakat.

a) Sosialisasi yang dilakukan pemerintah belum semua diterima dan diterapkan, Hasil analisa bagi beberapa kalangan dari segi politik masih ada yang kurang setuju terkait dengan kebijakan, komunikasi antar masyarakat dan pemerintah perlu di tingkatkan dalam mempublikasikan layanan pemerintah, fasilitas, dan teknologi yang ada didalam konsep Bandung smart city, dan masih seputar adanya isu sosial yang menjadi persoalan yang terjadi pada masyarakat prasejahtera. Hal ini termasuk kedalam akar permasalahan yang harus segera ditangani.

b) Penerapan konsep yang sama terkait dengan masa jabatan pemerintah masih sulit, Hasil analisa berkaitan dengan peraturan daerah mengenai rencana pembangunan dan rencana strategis kota Bandung. Hal ini termasuk kedalam akar permasalahan yang harus segera ditangani.

c) Regulasi dan Strategi, Hasil analisa kembali kepada masing - masing individu dari tiap lapisan masyarakat, pemerintah, ataupun swasta untuk berkomit terhadap jalannya aturan yang dibangun berdasarkan indikator yang dicanangkan perihal smart city di kota Bandung. Hal ini termasuk kedalam akar permasalahan yang harus segera ditangani. 
Infrastruktur

a) Fasilitas pengendalian banjir, drainase dan irigasi yg masih kurang, Hasil analisa beberapa daerah di kota Bandung masih terjadi adanya potensi banjir, untuk itu dibutuhkan infrastruktur yang kuat dalam pengendalian banjir.

b) Koneksi jaringan atau kabel jaringan belum merata atau memadai, Hasil analisa mengenai infrastruktur kabel jaringan melalui pipa dibawah tanah yang layaknya fiber optic. Hal ini termasuk kedalam akar permasalahan yang harus segera ditangani.

c) Masih minim infrastuktur komputer di beberapa daerah terkait pelayanan publik, Hasil analisa alat-alat penunjang teknologi informasi seperti komputer, di beberapa daerah terpencil khususnya dikantor-kantor pelayanan masyarakat belum cukup memadai.

d) Transportasi, Hasil analisa Infrastruktur mengenai penataan lalu lintas khususnya transportasi umum seperti angkot atau bus. Hal ini termasuk kedalam akar permasalahan yang harus segera ditangani.

Dengan mengetahui akar dari penyebab permasalahan yang telah dijelaskan diatas, merupakan hasil dari analisa yang dilakukan menggunakan cause effect atau fisbone diagram sehingga pemerintah kota dapat mengambil tindakan yang tepat untuk menangani dalam aspek smart city di kota Bandung.

\section{PENUTUP}

\section{Simpulan}

Terdapat empat kategori yang mengidentifikasi cakupan aspek Bandung Smart City. Simpulan yang didapat sebagai hasil penelitian dari tiap - tiap kategori adalah sebagai berikut:

a. Dalam kategori Man atau SDM yang menjadi sebab utama, memiliki beberapa yang terkait, yaitu masyarakat yang dimana tidak semua masyarakat dapat mengikuti atau menerapkan konsep Smart city dikota Bandung, misalnya dikalangan elit politik yang masih kurang setuju karena berbicara mengenai kebijakan, masyarakat yang masih kurang pemahamannya mengenai sistem atau aplikasi yang dihadirkan oleh pemerintah, masyarakat kecil atau masyarkat prasejahtera yang memiliki rasa berontak atau anarkis terhadap adanya implementasi Smart city di Kota Bandung mengakibatkan adanya ancaman isu sosial, sehingga membuat terhambatnya sosialisasi yang seharusnya merata di lapisan masyarakat, kemudian SDM dari pemerintah dirasa belum sesuai dengan skill atau kemampuan yang diusung oleh Smart city, dimana dibutuhkan adanya tenaga ahli teknologi informasi disetiap bagian pelayan masyarakat atau Satuan Kerja Perangkat Daerah. Dan terakhir tak kalah pentingnya, yaitu vendor atau investor atau pelaku rintisan yang biasa disebut dengan startup terkait mengenai kontrak kerja sama sistem atau aplikasi yang belum jelas.

b. Dalam Kategori Method atau Proses yang menjadi sebab utama, memiliki beberapa penyebab yang bercabang yaitu publikasi atau komunikasi yang kurang sehingga masih ada masyarakat yang belum mengetahui mengenai aplikasi atau sistem tersebut, Penerapan konsep yang sama terkait dengan masa jabatan pemerintah masih sulit, hal ini sudah jelas mengacu terhadap peraturan daerah, regulasi dan strategi.

c. Dalam Machine atau Teknologi yang menjadi sebab utama, memiliki beberapa penyebab yang bercabang yaitu aplikasi atau sistem yang masih sulit di operasikan baik itu pada masyarakat atau pun SKPD yang membutuhkan diklat khusus untuk meningkatkan kualitas SKPD. Dalam kategori Man sudah dijelaskan bahwasanya terkait purna jual sistem antara pemerintah dengan vendor yang belum pasti menjadikan pemeliharaan dan perawatan sistem atau aplikasi yang terintegrasi pun masih belum jelas dilakukan.

d. Dalam Infrastruktur yang menjadi sebab utama, memiliki beberapa penyebab yang bercabang yaitu masih dalam perbaikan untuk bisa membuat koneksi jaringan tersebar di seluruh wilayah kota Bandung dengan pengkabelan fiber optic atau LTE, penataan lalu lintas dan terkait dengan infrastruktur pelayanan masyarakat.

Demikian simpulan yang diatas berkaitan dengan dampak dari smart city dikota Bandung menggunakan analisa cause effect atau fishbone diagram. 


\section{Saran}

Berdasarkan simpulan yang telah dipaparkan maka peneliti dapat memberi saran sebagai berikut:

1. Perlu adanya sosialisasi untuk mengkomunikasikan atau mempublikasikan ke setiap lapisan masyarakat mengenai pemahaman mengenai sistem atau aplikasi yang terintegrasi di kota Bandung

2. Penataan kebijakan atau peraturan daerah yang diperlukan untuk merumuskan perencanaan atau strategi pengembangan Bandung Smart city, baik dalam pemerintah, vendor atau investor, elit politik, dan masyarakat, baik masyarakat milenial, masyarakat pra milenial, dan masyarakat prasejahtera.

3. Perlu mengkaji ulang perihal infrastuktur apa saja yang memang dibutuhkan oleh kota Bandung agar pembangunan konsep kota pintar dapat selaras, misalnya agar bisa dikatakan smart energi dapat dicanangkan tenaga surya panel dalam menghemat tenaga listrik, peningkatan keamanan sistem atau aplikasi yang lebih cerdas dengan adanya IoT atau Internet of Things.

\section{DAFTAR PUSTAKA}

Pratama, I Putu Agus Eka. 2014. Smart city Beserta Cloud Computing dan Teknologi teknologi pendukung lainnya.

Sugiyono. 2013. Metode penelitian kuantitatif, kualitatif dan r\&d, Bandung: Alfabeta.

Suyono, Yoyok yudistira. 2016. Bandung smart city- peran teknologi, Jakarta

Widyaningsih, Dwita. 2013. Thesis: Kota Surabaya Menuju Smart city. Yogyakarta: Universitas Gajah Mada

Mursalim, Siti Widharetno. 2017. Implementasi Kebijakan Smart city di Kota Bandung. Jurnal Ilmu Administrasi, Vol 14 No. 1

Hafedh Chourabi, Tae woo Nam, Shawan Walker, J.Ramon GilGarcia, Sehl Mellouli, Karine Nahon, Theresa A. Pardo, dan Hans Jochen Scholl. 2012. Understanding Smart Cities:An Integrative Framework, 45th Hawaii International Conference on System Sciences

Purba, H.H. (2008, September 25). Diagram fishbone dari Ishikawa. Retrieved from

http://hardipurba.com/2008/09/25/diagram-fishbone-dari-ishikawa.html

Tague, N. R. (2005). The quality toolbox. (2th ed.). Milwaukee, Wisconsin: ASQ Quality Press.

Available from http://asq.org/quality-press/display-item/index.html?item=H1224

Undang - undang No. 23 Tahun 2014 BAB XXI Pasal 386-390 Tentang Inovasi Pemerintah Daerah.

https://www.scribd.com/document/370015072/Bandung-Study-Book-ID (Diakses tanggal 27 Februari 2018).

https://lestarinurbudi.wordpress.com/2016/06/08/Bandung-smart-city/ (Diakses tanggal 27 Februari 2018). 